\title{
Reversal of multidrug resistance by magnetic
} $\mathrm{Fe}_{3} \mathrm{O}_{4}$ nanoparticle copolymerizating daunorubicin and MDRI shRNA expression vector in leukemia cells

\author{
This article was published in the following Dove Press journal: \\ International Journal of Nanomedicine \\ 19 June 2010 \\ Number of times this article has been viewed
}

\section{Bao-an Chen' \\ Pei-pei Mao' \\ Jian Cheng' \\ Feng Gao' \\ Guo-hua Xia' \\ Wen-lin $\mathrm{Xu}^{2}$ \\ Hui-lin Shen ${ }^{2}$ \\ Jia-hua Ding' \\ Chong Gao' \\ Qian Sun' \\ Wen-ji Chen' \\ Ning-na Chen' \\ Li-jie Liu $^{3}$ \\ Xiao-mao $\mathrm{Li}^{4}$ \\ Xue-mei Wang ${ }^{5}$ \\ 'Department of Hematology, The Affiliated Zhongda Hospital, Clinical Medical School, Southeast University, Nanjing, People's Republic of China; ${ }^{2}$ Department of Hematology, The Affiliated People's Hospital, Jiangsu University, Zhenjiang, People's Republic of China; ${ }^{3}$ Institution of Physiology, Southeast University, Nanjing, People's Republic of China; ${ }^{4}$ Department of Physics, University of Saarland, Saarbruecken, Germany; ${ }^{5}$ State Key Lab of Bioelectronics (Chien-Shiung Wu Laboratory), Southeast University, Nanjing, People's Republic of China}

Correspondence: Pei-pei Mao Department of Hematology, The Affiliated Zhongda Hospital, Clinical Medical School, Southeast University, Nanjing, 210009

People's Republic of China

Tel +8625 I380 I596325

Email alicemm634801587@qq.com

\begin{abstract}
In many instances, multidrug resistance (MDR) is mediated by increasing the expression at the cell surface of the MDR1 gene product, P-glycoprotein (P-gp), a 170-kD energy-dependent efflux pump. The aim of this study was to investigate the potential benefit of combination therapy with magnetic $\mathrm{Fe}_{3} \mathrm{O}_{4}$ nanoparticle $\left[\mathrm{MNP}\left(\mathrm{Fe}_{3} \mathrm{O}_{4}\right)\right.$ ] and MDR1 shRNA expression vector in K562/A02 cells. For stable reversal of "classical" MDR by short hairpin RNA (shRNA) aiming directly at the target sequence (3491-3509, 1539-1557, and 3103-3121 nucleotide) of MDR1 mRNA. PGC silencer-U6-neo-GFP-shRNA/MDR1 called PGY1-1, PGY1-2, and PGY1-3 were constructed and transfected into K562/A02 cells by lipofectamine 2000. After transfected and incubated with or without MNP $\left(\mathrm{Fe}_{3} \mathrm{O}_{4}\right)$ for 48 hours, the transcription of MDR1 mRNA and the expression of P-gp were detected by quantitative real-time PCR and Western-blot assay respectively. Meanwhile intracellular concentration of DNR in K562/A02 cells was detected by flow cytometry (FCM). PGC silencer-U6-neo-GFP-shRNA/MDR1 was successfully constructed, which was confirmed by sequencing and PGY1-2 had the greatest MDR1 gene inhibitory ratio. Analysis of the reversal ratio of MDR, the concentration of daunorubicin (DNR) and the transcription of MDR1 gene and expression of P-gp in K562/A02 showed that combination of DNR with either MNP $\left(\mathrm{Fe}_{3} \mathrm{O}_{4}\right)$ or PGY1-2 exerted a potent cytotoxic effect on K562/A02 cells, while combination of $\mathrm{MNP}\left(\mathrm{Fe}_{3} \mathrm{O}_{4}\right)$ and $\mathrm{PGY} 1-2$ could synergistically reverse multidrug resistance. Thus our in vitro data strongly suggested that a combination of $\mathrm{MNP}\left(\mathrm{Fe}_{3} \mathrm{O}_{4}\right)$ and shRNA expression vector might be a more sufficient and less toxic anti-MDR method on leukemia.
\end{abstract}

Keywords: K562/A02 cell line, multidrug resistance, magnetic nanoparticle of $\mathrm{Fe}_{3} \mathrm{O}_{4}$, recombinant plasmid vector PGY1-2

\section{Introduction}

Multidrug resistance (MDR) is a well-defined phenomenon of cross-resistance of mammalian cells to a number of anticancer agents following exposure to one such drug. It is a major obstacle to successful chemotherapy in leukemia and more than $90 \%$ of patients with malignant tumor died of MDR. ${ }^{1}$ A diverse range of agents involved in MDR include alkaloid compounds, bacterial and fungal antibiotics such as anthracyclines and etoposide. An accepted mechanism of MDR is related to a reduced intracellular accumulation and the altered subcellular distribution of toxic drugs, which is mediated by over expression of P-glycoprotein (P-gp) at the cell surface in many instances. P-gp, which is encoded by the MDR1 gene, is a major organic action transporter in tissues responsible for the excretion of xenobiotics (both drugs and toxins) by the biliary tract and proximal tubule of the kidney, so as to decrease intracellular drug accumulation. 
It is generally accepted that any access which could increase the effective concentration of intracellular chemotherapeutic agent was available to enhance the agent therapy.

In recent years, drugs packaged by liposome or multimer have been developed. Nanoparticle techniques have been paid more close attention and nanoparticles have been introduced as drug delivery systems to enhance the efficiency of anticancer drug delivery based on the ability to target specific locations in the body. ${ }^{2} \mathrm{MNP}\left(\mathrm{Fe}_{3} \mathrm{O}_{4}\right)$ described in our previous studies have good biocompatibility and low cytotoxicity, ${ }^{3,4}$ which could increase the intracellular effective concentration of chemotherapeutic drugs in vitro so as to reverse MDR. ${ }^{5,6}$ Some other reports have demonstrated that $\mathrm{MNP}\left(\mathrm{Fe}_{3} \mathrm{O}_{4}\right)$ has the synergistic effect with the anticancer drug DNR on the drug accumulation of leukemia cells both in vitro and in vivo., ${ }^{4,8}$ The diameter of $\mathrm{MNP}\left(\mathrm{Fe}_{3} \mathrm{O}_{4}\right)$ manufactured by Biological Science College of Southeast University is $20-30 \mathrm{~nm} .{ }^{7}$ An understanding of the interface between the MNP $\left(\mathrm{Fe}_{3} \mathrm{O}_{4}\right)$ and anticancer agents to reverse MDR, for their application and safety, are imperative to advance nanomedicine.

Another key problem for tumor treatment, as we know, is to reduce the sensitivity of tumor cells to cytotoxic drugs. Such an alternative procedure to circumvent MDR1/P-gp mediated MDR in cancer cells is to prevent the biosynthesis of MDR1/P-gp by gene therapeutic technologies. RNA interference (RNAi) technology is currently used not only as a powerful tool for analyzing gene function, but also for developing highly specific therapeutics, ${ }^{9-11}$ which relies on the sequence-specific interaction between small interfering RNA (siRNAs) and mRNA. Degradation of long double-stranded RNA to siRNA is mediated by a double-stranded RNA-specific RNase III Dicer. The siRNAs are incorporated into a nuclease complex known as RNAinduced silencing complex (RISC), where unwinding of the duplex siRNAs takes place. The antisense strand binds in a highly sequence-specific manner to target mRNA, which is then endonucleolytically cleaved and degraded. ${ }^{7}$ It has recently been shown that RNAi can be achieved in cultured mammalian cells using siRNAs with a length of 21-23 bp. ${ }^{12}$ However, the half-life of P-gp (at least $16 \mathrm{~h}$ ) makes it difficult to achieve a complete knock-down of P-gp. ${ }^{13}$ Little in vitro data is available in investigating the combination of MNP $\left(\mathrm{Fe}_{3} \mathrm{O}_{4}\right)$ with siRNA for reversing MDR. Therefore, the effective shRNA PGY1-2, is used to be combined with MNP $\left(\mathrm{Fe}_{3} \mathrm{O}_{4}\right)$ to sensitize MDR cells as anticancer agents in vitro, and to find a low mammalian toxicity, high-efficiency and high-selectivity modulator.

\section{Materials and methods \\ Main reagents}

Adriamycin $^{\circledR}$ (ADM; Hisun Pharmaceutical Co, Zhejiang, China) and daunorubicin (DNR; Main Luck Pharmaceuticals Inc., Shenzhen, China) stock solution $(2 \mathrm{mg} / \mathrm{mL})$ were prepared with $0.01 \mathrm{~mol} / \mathrm{L}$ phosphate buffer saline (PBS, pH7.4). Nanoparticles $\mathrm{Fe}_{3} \mathrm{O}_{4}$ (State Key Lab of Bioelectronics, Chien-Shiung Wu Laboratory, Southeast University, Nanjing, China) were well distributed in RPMI 1640 medium (Gibco ${ }^{\circledast} / \mathrm{BRL}$, Carlsbad, CA, USA) containing $10 \%(\mathrm{v} / \mathrm{v})$ heat-inactivated new-born calf serum (Sijiqing, Hangzhou, China) by using ultrasound treatment in order to obtain MNP $\left(\mathrm{Fe}_{3} \mathrm{O}_{4}\right.$ ) colloidal suspension. $1.0 \mu \mathrm{g} / \mathrm{mL}$ DNR conjugated with $10 \mu \mathrm{g} / \mathrm{mL} \mathrm{MNP}\left(\mathrm{Fe}_{3} \mathrm{O}_{4}\right)$ were prepared by mechanical absorption polymerization at $4^{\circ} \mathrm{C}$ for 48 hours as previously. ${ }^{8,14}$ T4 DNA ligase, BamHI, Hind III NEB. Opti-MEM ${ }^{\circledR}\left(\right.$ Gibco $\left.^{\circledR}\right)$. Trizol ${ }^{\circledR}$ reagent (Invitrogen Life Technologies, Carlsbad, CA, USA); SYBR ${ }^{\circledR}$ Green I dye (Takara, Shiga, Japan); Rotor-Gene 3000 (Corbett Research, Sydney, Australia).

\section{Cell lines and culture conditions}

Human leukemia cell line K562 and its Adriamycin ${ }^{\circledR}$-selected P-gp-over expressing subline K562/A02 were obtained from the Institute of Hematology, Chinese Academy of Medical ZSciences (Tianjin, China). Both cells were cultured in RPMI 1640 medium (Gibco $\left.{ }^{\circledR} / \mathrm{BRL}\right)$ containing 10\% (v/v) heat-inactivated new-born calf serum, $100 \mathrm{U} / \mathrm{mL}$ penicillin, and $100 \mu \mathrm{g} / \mathrm{mL}$ streptomycin at $37^{\circ} \mathrm{C}, 5 \% \mathrm{CO}_{2}$ incubator. K562/A02 was cultured in the medium containing $1 \mu \mathrm{g} / \mathrm{mL}$ ADM for maintaining MDR phenotype, and maintained in drug-free medium for at least seven days before use. Briefly, cells were incubated with $\mathrm{MNP}\left(\mathrm{Fe}_{3} \mathrm{O}_{4}\right)$ and/or PGY1-2 at $37^{\circ} \mathrm{C}$ for 48 hours.

\section{Vector construction and identification}

Three 19-nt siRNAs targeting different nucleotide sites of MDR1 mRNA (M14758.1) designed according to the Tuschl principles $^{7}$ were 5'-GGCCTAATGCCGAACACAT-3' (34913509 nt); 5'-GTATTGACAGCTATTC GAA-3'(1539-1557 nt) and 5'-GATCGCTAC TGAAGCAATA-3'(3103-3121 nt). BLAST research was performed to ensure that the shRNAs did not have significant sequence homology with other genes. The 66-nt oligonucleotides were annealed and cloned into the BamHI and HindIII sites of the PGC silencer-U6-neo-GFP vector. The shRNA expression vectors called PGY1-1, PGY1-2, and PGY1-3 were designated and confirmed by sequencing. 


\section{Transfection}

The human leukemia cell line K562/A02 was transfected in Opti-MEM ${ }^{\circledR}$ I medium using Lipofectamine ${ }^{\text {TM }} 2000$ (Invitrogen) under serum-free conditions according to the manufacturer's recommendations. The plasmid $(\mu \mathrm{g})$ to Lipofectamine $2000(\mu \mathrm{L})$ was used to prepare for complexes at the ratio of 2:5. Cells were incubated at $37^{\circ} \mathrm{C}$ in a $5 \% \mathrm{CO}_{2}$ incubator for 48 hours for transgene expression. After staining with $\mathrm{SYBR}^{\circledR}$ Green I, the cells were calculated and differentiated according to whether the cell could light green fluorescence or not under the fluorescence microscope. The transfected efficiency was calculated by the ratio of transfected cells in one hundred of K562/A02 cells.

\section{Cytotoxicity assay}

The in vitro chemosensitivity was measured by 3-(4, 5-dimethylthiazol-2-yl)-2, 5-diphenyltetrazolium bromide (MTT) (Sigma Aldrich, USA) assay. Account for the results of transfection and our previous reports, $1.3 \mu \mathrm{g} / \mathrm{mL}$ PGY1-2 vector, and $10 \mu \mathrm{g} / \mathrm{mL} \mathrm{MNP}\left(\mathrm{Fe}_{3} \mathrm{O}_{4}\right)^{7,8}$ were selected for our study. Briefly, $1.5 \times 10^{5} / \mathrm{mL}$ cells were suspended in $100 \mu \mathrm{L}$ culture medium on 96-well culture plate (Costar; Fisher Scientific, Hampton, NH, USA) per well. To determine the antiproliferative effect of PGY1-2, MNP $\left(\mathrm{Fe}_{3} \mathrm{O}_{4}\right)$ or DNR, a different concentration of DNR with or without $10 \mu \mathrm{g} / \mathrm{mL}$ $\operatorname{MNP}\left(\mathrm{Fe}_{3} \mathrm{O}_{4}\right)$ and $1.3 \mu \mathrm{g} / \mathrm{mL}$ PGY1-2 vector were added into $100 \mu \mathrm{L}$ dilution of the culture medium. Meanwhile, RPMI 1640 medium was regarded as the bank control and cells without reagents were the negative control. After incubation for 48 hours at $37^{\circ} \mathrm{C}, 20 \mu \mathrm{L}$ MTT $(0.5 \mathrm{mg} / \mathrm{mL})$ were added to each well and cultured for another 4 hours. The formazan was dissolved with $150 \mu \mathrm{L}$ dimethyl sulfoxide (Sigma Aldrich, USA) after blotting the culture medium. The plates were shaken lightly for 10 minutes, and the reduction of MTT was quantified by absorbance at a wavelength of $540 \mathrm{~nm}$ using a microplate reader (Model-550; Bio-Rad Laboratories, Hercules, CA, USA).

\section{Quantitative real-time PCR analysis}

After treatment with drugs as described in cytotoxicity assay, total RNA was isolated using Trizol reagent according to the manufacturer's protocol. One microgram of RNA was used to generate cDNA using SuperScript ${ }^{\mathrm{TM}}$ II Reverse Transcriptase (Invitrogen Life Technologies). Primers involved were the MDR1 (205 bp) primers (forwards 5'-CCATCATTGCAATA GCAGG-3', reverse 5'-AGGAGCAGAAGT TTGAAC-3') and the GAPDH primers (forwards 5'-CGGATTTGGTCGTAT TG-3', reverse 5'-GAAGATGGTGATGGGATT-3'). QPCR was performed by monitoring in real-time the increase of fluorescence of SYBR ${ }^{\circledR}$ Green I dye with Rotor-Gene 3000 (Corbett Research, Sydney Australia). The relative gene copy number was calculated by the concentration-CT standard curve method and normalized using the average expression of GAPDH.

\section{Western blot analysis}

In order to examine the expression of P-gp, Western-blot assay was performed to analyze the level of protein from cells treated for 48 hours as described previously. ${ }^{8}$ Briefly, total protein was isolated and subjected to $10 \%$ sodium dodecyl sulfate PAGE, and transferred to a polyvinylidene difluoride membrane (Bio-Rad, Hercules, CA). The blots were stained with mouse anti-P-gp or mouse anti- $\beta$-actin $(1: 1000-1: 1200)$ in $5 \%$ nonfat dry milk overnight at $4{ }^{\circ} \mathrm{C}$, and then with horseradish peroxidase conjugated goat antirabbit as a secondary antibody (1:5000) for 1 hour at room temperature. The signal was detected with the enhanced chemiluminescence (ECL) Western Blotting Detection Kit (Zhong Shan Co, Beijing, China). After normalization by the corresponding expression of $\beta$-actin, the levels of P-gp protein expression were determined by densitometry scans (ECL system, Amersham, UK).

\section{Cellular accumulation of DNR}

The intracellular concentration of DNR in K562/A02 cells was determined by flow cytometry (FCM) assay. Briefly, K562/A02 cells were treated as described in cytotoxicity assay, collected and then incubated with CD34-FITC for 15 minutes. After being washed with PBS three times, cells were suspended and determined by a FCM (Becton Dickinson, USA) assay at excitation and emission wavelengths of $488 \mathrm{~nm}$ and $575 \mathrm{~nm}$, respectively.

\section{Statistical analysis}

All experiments were repeated at least three times, data were expressed as mean \pm SD and analyzed with the Statistical Package for Social Science (SPSS Release 11.5; SPSS Inc., Chicago, IL, USA). Differences among various groups were evaluated using one-way ANOVA. A $P$ value of 0.05 was considered to be statistically significant.

\section{Results Vector feature}

According to the targeting sequences, three pairs of 66-nt oligonucleotides coding shRNAs containing 19-nt reverted repeat, 9-nt linker sequence for all hairpins, HindIII 
and BamHI restriction enzyme sites were designed and synthesized (Figure 1).

\section{Sequencing results}

The shRNA expression vector called PGY1-1, PGY1-2 and PGY1-3 were designated by sequencing. Based on the sequencing of PGY1-1, PGY1-2 and PGY1-3, shRNA was cloned into the vector successfully, respectively. (Figures 2 A, B, C).

\section{Transfected cell morphology}

When the recombinant plasmids having GFP gene were transfected into K562/AO2 cells successfully, green fluorescence could be observed in these cells under fluorescence microscope. The transfected efficiency was $19.9 \% \pm 1.2 \%$, while there were no green fluorescence observed in the cells of control group $(P<0.05)$ (Figure 3$)$.

\section{Screening masculine clone}

The transcription of MDR1 was significantly lower in K562/ A02 cells transfected with PGY1-1, PGY1-2 or PGY1-3 than that in control group $(P<0.05)$. Furthermore, the transcription of MDR1 in K562/A02 transfected with PGY1-2 was less than that in transfected cells with PGY1-1 or PGY1-3 $(P<0.05)$, suggesting the PGY1-2 was the masculine clone we wanted to choose, which was further demonstrated by our Western-blot assay. Lower expression of P-gp in K562/A02 transfected with PGY1-2 than that in

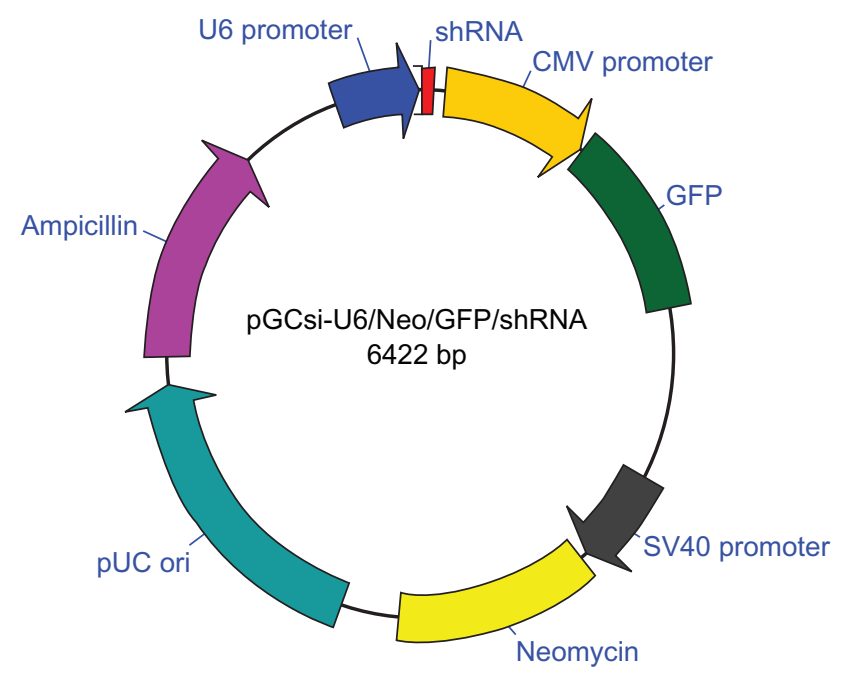

Figure I Construction of PGC silencer-U6-neo-GFP-shRNA expression system. Notes: U6 Promoter: 6077-6422; shRNA: 9-55; CMV promoter: 105-704; GFP: 709-I428; SV40 Promoter: 2098-2475; Neomycin: 2503-3297; pUC ori: 3534-4702; Ampicillin: 4805-5659. cells transfected with PGY1-1 or PGY1-3 was detected by ECL system $(P<0.05)$ (Figure 4$)$.

\section{Cell growth and inhibition}

The MTT assay revealed that the growth and inhibition of DNR, MNP $\left(\mathrm{Fe}_{3} \mathrm{O}_{4}\right)$ with DNR, PGY1-2 with DNR, MNP $\left(\mathrm{Fe}_{3} \mathrm{O}_{4}\right)$ and PGY1-2 with DNR to K562/A02 cells. MNP $\left(\mathrm{Fe}_{3} \mathrm{O}_{4}\right)$ and PGY1-2 symphysially showed significant reversal effect on DNR resistance in K562/A02 cell line, and its potency was greater than using $\mathrm{MNP}\left(\mathrm{Fe}_{3} \mathrm{O}_{4}\right)$ and PGY1-2 alone. The inhibitory concentration at $50 \%$ $\left(\mathrm{IC}_{50}\right)$ of DNR decreased from $(14.82 \pm 0.96) \mu \mathrm{g} / \mathrm{mL}$ to $(0.97 \pm 0.41) \mu \mathrm{g} / \mathrm{mL}(P<0.05)$ at the combination of $10 \mu \mathrm{g} / \mathrm{mL} \mathrm{MNP}\left(\mathrm{Fe}_{3} \mathrm{O}_{4}\right)$ and $1.3 \mu \mathrm{g} / \mathrm{mL}$ PGY1-2 with DNR, while the values were down to $(4.75 \pm 0.59) \mu \mathrm{g} / \mathrm{mL}$ and $(1.08 \pm 0.37) \mu \mathrm{g} / \mathrm{mL}$ for $\mathrm{MNP}\left(\mathrm{Fe}_{3} \mathrm{O}_{4}\right)$ and PGY1-2, respectively $(P<0.05)$. The fold reversals were 15.3 of the synergia compared with the 3.15 of $\mathrm{MNP}\left(\mathrm{Fe}_{3} \mathrm{O}_{4}\right)$ and 13.7 of PGY1-2 alone (Table 1).

\section{Transcription of MDR I by QPCR}

To determine whether the shRNA expression vectors targeting MDR1 gene combined with $\mathrm{MNP}\left(\mathrm{Fe}_{3} \mathrm{O}_{4}\right)$ could downregulate gene expression, K562/A02 cells were transfected with PGY1-2. DNR in the absence or presence of MNP $\left(\mathrm{Fe}_{3} \mathrm{O}_{4}\right)$ or vector PGY1-2 all down-regulated the transcription of MDR1 in K562/A02 cells, these were statistically significant when compared to parented sensitive K562 cells $(P<0.05)$. Interestingly, MNP $\left(\mathrm{Fe}_{3} \mathrm{O}_{4}\right)$ and PGY1-2 with DNR together decreased the expression of MDR1 mRNA more effectively than MNP $\left(\mathrm{Fe}_{3} \mathrm{O}_{4}\right)$ or PGY1-2 with DNR, respectively $(P<0.05)$ (Figure 5$)$, suggesting the combination of MNP $\left(\mathrm{Fe}_{3} \mathrm{O}_{4}\right)$ and PGY1-2 has a potential benefit to sensitize MDR cells for down-regulating the transcription of MDR1.

\section{Expression of P-gp protein by Western-blot assay}

The effect of the shRNA/MDR1 on P-gp expression was determined by measuring cell surface P-gp. The inhibitory effect of shRNA expression vector combined with MNP $\left(\mathrm{Fe}_{3} \mathrm{O}_{4}\right)$ on cellular P-gp in K562/A02 cells was assayed by Western-blot assay (Figure 6). The expression of P-gp in $\mathrm{K} 562 / \mathrm{A} 02$ cells incubated with combination of $\mathrm{MNP}\left(\mathrm{Fe}_{3} \mathrm{O}_{4}\right)$ and PGY1-2 with DNR was decreased than that with shRNA expression vector or MNP $\left(\mathrm{Fe}_{3} \mathrm{O}_{4}\right)$, respectively $(P<0.05)$, suggesting that $\mathrm{MNP}\left(\mathrm{Fe}_{3} \mathrm{O}_{4}\right)$ and PGY1-2 together has a potential benefit to sensitize MDR cells down-regulating the expression of $\mathrm{P}$-gp. 


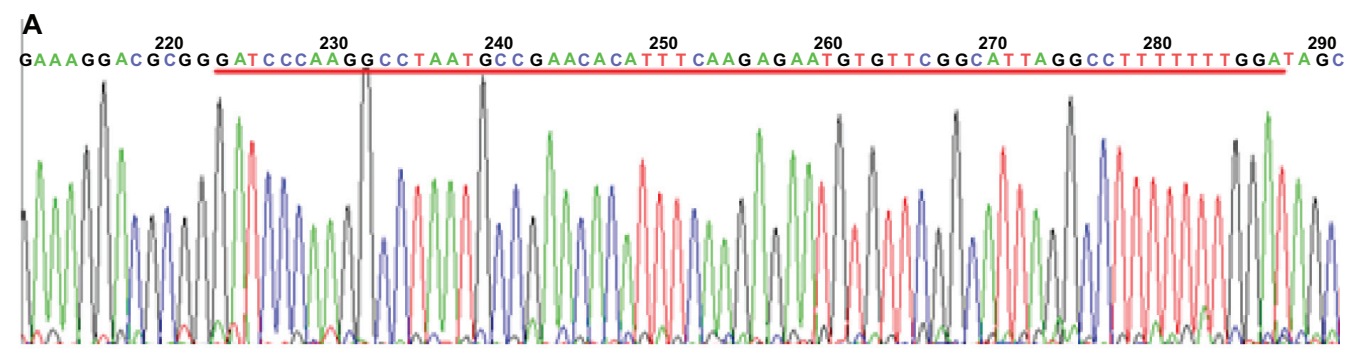

B

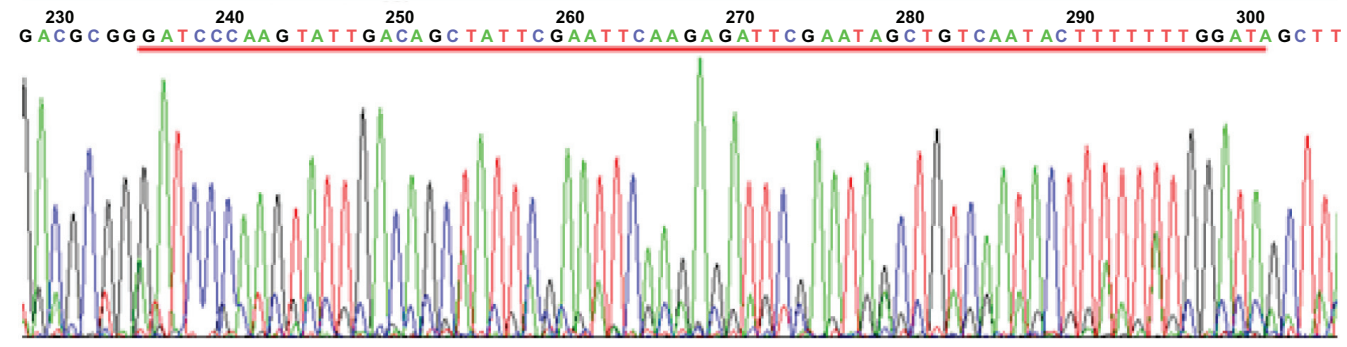

C

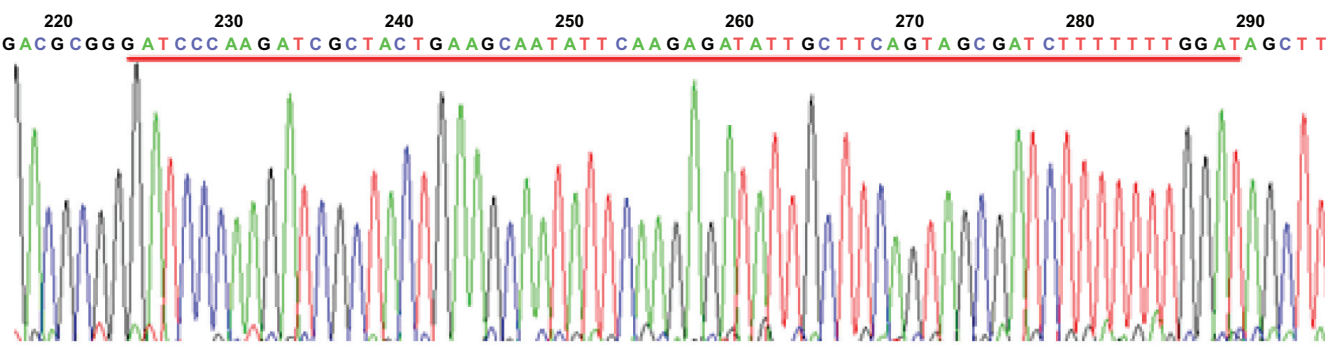

Figure 2 Sequence of shRNA/MDRI.

Notes: A) PGYI-I; B) PGYI-2; C) PGYI-3.

\section{Intracellular concentration of DNR}

The intracellular concentration of DNR in K562/A02 cells was explored by FCM assay after incubated for 48 hours. The mean fluorescence intensity of K562/A02 cells incubated with $0 \mu \mathrm{g} / \mathrm{mL}$ DNR was $170 \pm 12$; with DNR, $2490 \pm 19$; with $\operatorname{MNP}\left(\mathrm{Fe}_{3} \mathrm{O}_{4}\right)$ and DNR, $3318 \pm 22$; with PGY1-2 and DNR,

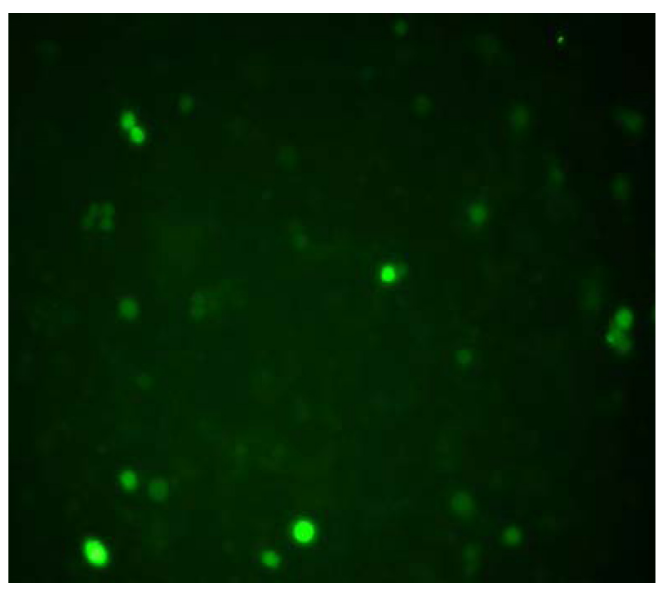

Figure 3 Morphology of $\mathrm{K} 562 / \mathrm{A02}$ cells after transfected for 48 hours under fluorescence microscope $\left(400 \times \mathrm{SYBR}^{\circledR}\right.$ Green I staining).
$5513 \pm 20$; and with combination of DNR, MNP $\left(\mathrm{Fe}_{3} \mathrm{O}_{4}\right)$ and PGY1-2, $6930 \pm 12$, implicating that $\mathrm{MNP}\left(\mathrm{Fe}_{3} \mathrm{O}_{4}\right)$ and PGY1-2 with DNR together increased the intracellular DNR in $\mathrm{K} 562 / \mathrm{AO} 2$ cells more effectively than that of $\mathrm{MNP}\left(\mathrm{Fe}_{3} \mathrm{O}_{4}\right)$ or PGY1-2 with DNR respectively (Figure 7).

\section{Discussion}

It is generally accepted that any access which could increase the effective concentration of intracellular chemotherapeutic agent was available to enhance the agent therapy. P-gp, among other ATP-binding cassette transporters, has important clinical implications since it is responsible for excretion of drugs and exotoxins and for resistance to multiple chemotherapeutic agents. ${ }^{15}$ The over-expression of P-gp in human tumors appears either at the time of diagnosis or prognosis. Inhibition of the function or expression of P-gp may result in re-sensitization of tumor cells to treatment with antineoplastic. ${ }^{16}$

To increase the intracellular effective concentration of chemotherapeutic agent, drugs packaged by liposome or multimer have been developed recently, as one of the most commonly used magnetic nanoparticles, $\mathrm{MNP}\left(\mathrm{Fe}_{3} \mathrm{O}_{4}\right)$ are 
A
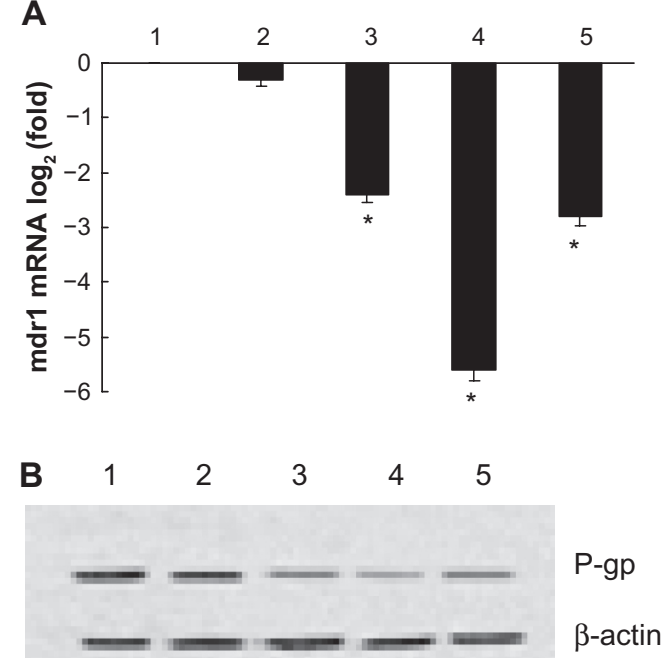

Figure 4 Effects of shRNA expression vectors on MDRI mRNA and its protein in K562/A02 cells after treatment for 48 hours. A) Transcription of MDRI mRNA detected by quantitative real-time PCR described before; B) Expression of P-gP determined by Western-blot analysis described before.

Notes: I. Negative control (PGC silencer-U6-neo-GFP empty plasmid); 2. Positive control (PGC silencer-U6-neo-GFP GAPDH plasmid); 3. PGYI-I; 4. PGYI-2; 5. PGYI-3. $* P<0.05$, when compared to positive control group; $P<0.05$, the group of transfected cells with PGYI-2 was less than that of transfected cells with PGYI-I or PGYI-3.

more easily gained than others and they may aggregate in water or tissue fluid spontaneously with good biocompatibility and low toxicity. ${ }^{17} \mathrm{MNP}\left(\mathrm{Fe}_{3} \mathrm{O}_{4}\right)$ are widely used for targeted-drug carriers with target-orientation and sustainedrelease properties. ${ }^{18}$ Previous studies have demonstrated the synergistic effect of $\mathrm{MNP}\left(\mathrm{Fe}_{3} \mathrm{O}_{4}\right)$ with anticancer drug on the drug accumulation of leukemia K562 cells may help it to inhibit the relative drug resistance. ${ }^{2}$ Similar results were observed in our study, it showed that after incubation with different agents for 48 hours, fluorescence intensity of K562/ A02 was increased when compared to control group. Interestingly, fluorescence intensity of K562/A02 treated with DNR, $\mathrm{MNP}\left(\mathrm{Fe}_{3} \mathrm{O}_{4}\right)$ and PGY1-2 was more intensified than that of $\mathrm{MNP}\left(\mathrm{Fe}_{3} \mathrm{O}_{4}\right)$ or PGY1-2 with DNR respectively, implicating

Table I The cytotoxicity of DNR, MNP $\left(\mathrm{Fe}_{3} \mathrm{O}_{4}\right)$ with DNR, PGYI-2 with DNR, MNP $\left(\mathrm{Fe}_{3} \mathrm{O}_{4}\right)$ and PGYI-2 with DNR on K562/A02 for 48 hours determined by MTT assay (mean \pm SD)

\begin{tabular}{|c|c|}
\hline Groups & IC ${ }_{50}$ of DNR $(\mu \mathrm{g} / \mathrm{mL})$ \\
\hline \multicolumn{2}{|l|}{ DNR I $4.82 \pm 0.96$} \\
\hline $10 \mu \mathrm{g} / \mathrm{mL} \mathrm{MNP}\left(\mathrm{Fe}_{3} \mathrm{O}_{4}\right)+\mathrm{DNR}$ & $4.75 \pm 0.59(3.15)^{*}$ \\
\hline $1.3 \mu \mathrm{g} / \mathrm{mL}$ PGYI-2 + DNR & $1.08 \pm 0.37(13.7)^{*}$ \\
\hline \multicolumn{2}{|l|}{$10 \mu \mathrm{g} / \mathrm{mL} \mathrm{MNP}\left(\mathrm{Fe}_{3} \mathrm{O}_{4}\right)+$} \\
\hline $1.3 \mu \mathrm{g} / \mathrm{mL}$ PGYI-2 + DNR & $0.97 \pm 0.4 \mathrm{I}(15.3)^{*}$ \\
\hline
\end{tabular}

Notes: The values in parentheses were fold reversal (FR) calculated as follows: $\mathrm{FR}=\mathrm{IC}_{50 \text { DNR alone }} / I \mathrm{C}_{50 \mathrm{DNR}+\text { agent }} * P<0.05$, compared with DNR group.

Abbreviations: DNR, daunorubicin; FR, fold reversal; $\mathrm{IC}_{50}$, inhibitory concentration at $50 \%$; $\mathrm{MNP}\left(\mathrm{Fe}_{3} \mathrm{O}_{4}\right)$, magnetic nanoparticles of $\mathrm{Fe}_{3} \mathrm{O}_{4}$;rate; $\mathrm{SD}$, standard deviation.

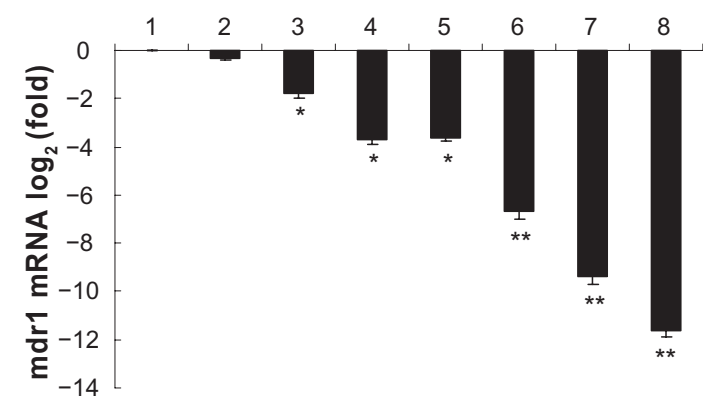

Figure 5 Effects of MNP $\left(\mathrm{Fe}_{3} \mathrm{O}_{4}\right)$ and/or PGYI-2 on MDRI mRNA in $\mathrm{K} 562$ cells and K562/A02 cells after treatment for 48 hours by Quantitative real-time PCR analysis.

Notes: I. K562/A02-untreated; 2. K562/A02 treated with $1.0 \mu \mathrm{g} / \mathrm{mL}$ DNR; 3. K562/ $\mathrm{A} 02$ treated with $10 \mu \mathrm{g} / \mathrm{mL} \mathrm{MNP}\left(\mathrm{Fe}_{3} \mathrm{O}_{4}\right) ; 4$. K562/A02 treated with PGYI-2; 5. K562/ $\mathrm{A} 02$ treated with $10 \mu \mathrm{g} / \mathrm{mL} \mathrm{MNP}\left(\mathrm{Fe}_{3} \mathrm{O}_{4}\right)$ and I.0 $\mu \mathrm{g} / \mathrm{mL}$ DNR; 6. K562/A02 treated with PGYI-2 and I.0 $\mu \mathrm{g} / \mathrm{mL}$ DNR; 7. $\mathrm{K} 562 / \mathrm{A0} 2$ treated with $10 \mu \mathrm{g} / \mathrm{mL} \mathrm{MNP}\left(\mathrm{Fe}_{3} \mathrm{O}_{4}\right)$, PGYI-2 and I.0 $\mu \mathrm{g} / \mathrm{mL}$ DNR; 8. K562-untreated. $* P<0.05$, when compared to $\mathrm{K} 562 / \mathrm{A0} 02$ incubated with $1.0 \mu \mathrm{g} / \mathrm{mL} \mathrm{DNR}$; $* * P<0.05$, when compared to $\mathrm{K} 562 /$ A02 incubated with $1.0 \mu \mathrm{g} / \mathrm{mL}$ DNR in the presence of PGYI-2 or MNP $\left(\mathrm{Fe}_{3} \mathrm{O}_{4}\right)$. Abbreviations: MNP $\left(\mathrm{Fe}_{3} \mathrm{O}_{4}\right)$, magnetic nanoparticles of $\mathrm{Fe}_{3} \mathrm{O}_{4}$; DNR, daunorubicin.

that MNP $\left(\mathrm{Fe}_{3} \mathrm{O}_{4}\right)$ and PGY1-2 with DNR together could increase the intracellular concentration of DNR in K562/ $\mathrm{AO} 2$ cells more effectively.

To further evaluate $\mathrm{MNP}\left(\mathrm{Fe}_{3} \mathrm{O}_{4}\right)$ and shRNAs on reversal of multidrug resistance cells, the shRNA expression vectors called PGY1-1, PGY1-2 and PGY1-3were designated and confirmed by sequencing. The introduction of short, doublestranded RNA complexes by transfection have been found to be a very efficient way to knock down gene expression in mammalian cells. ${ }^{6}$ Recently, a number of studies have shown that shRNAs transcribed under the control of RNA polymerase III (Pol III) promoters effectively degrade mRNAs in culture cells. siRNA technology is an efficient tool for the specific knockdown of a given target mRNA. Up to now, mainly

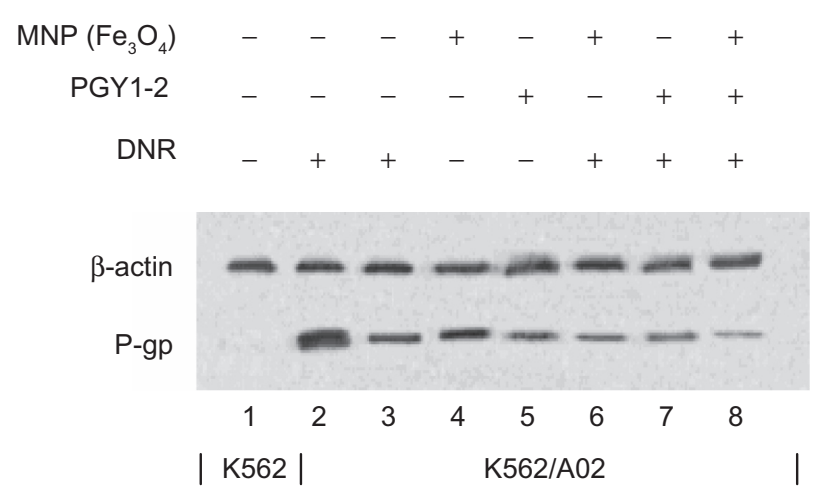

Figure 6 Effects of MNP $\left(\mathrm{Fe}_{3} \mathrm{O}_{4}\right)$ and/or PGYI-2 with DNR on P-gP in $\mathrm{K} 562$ cells and $\mathrm{K} 562 / \mathrm{A} 02$ cells for 48 hours by Western-blot assay.

Notes: I. K562-untreated; 2. K562/A02-untreated; 3. K562/A02 treated with $1.0 \mu \mathrm{g} / \mathrm{mL}$ DNR; 4. K562/A02 treated with $10 \mu \mathrm{g} / \mathrm{ml} \mathrm{MNP}\left(\mathrm{Fe}_{3} \mathrm{O}_{4}\right) ; 5 . \mathrm{K} 562 / \mathrm{A0} 2$ treated with PGYI-2; 6. K562/A02 treated with $10 \mu \mathrm{g} / \mathrm{ml} \mathrm{MNP}\left(\mathrm{Fe}_{3} \mathrm{O}_{4}\right)$ and I.0 $\mu \mathrm{g} / \mathrm{ml}$ DNR; 7. K562/A02 treated with PGYI-2 and $1.0 \mu \mathrm{g} / \mathrm{ml} \mathrm{DNR;} \mathrm{8.} \mathrm{K562/A02} \mathrm{treated}$ with $10 \mu \mathrm{g} / \mathrm{ml} \mathrm{MNP}\left(\mathrm{Fe}_{3} \mathrm{O}_{4}\right), \mathrm{PGYI}-2$ and $\mathrm{I} .0 \mu \mathrm{g} / \mathrm{ml} \mathrm{DNR}$.

Abbreviations: $\mathrm{MNP}\left(\mathrm{Fe}_{3} \mathrm{O}_{4}\right)$, magnetic nanoparticles of $\mathrm{Fe}_{3} \mathrm{O}_{4}$; DNR, daunorubicin. 

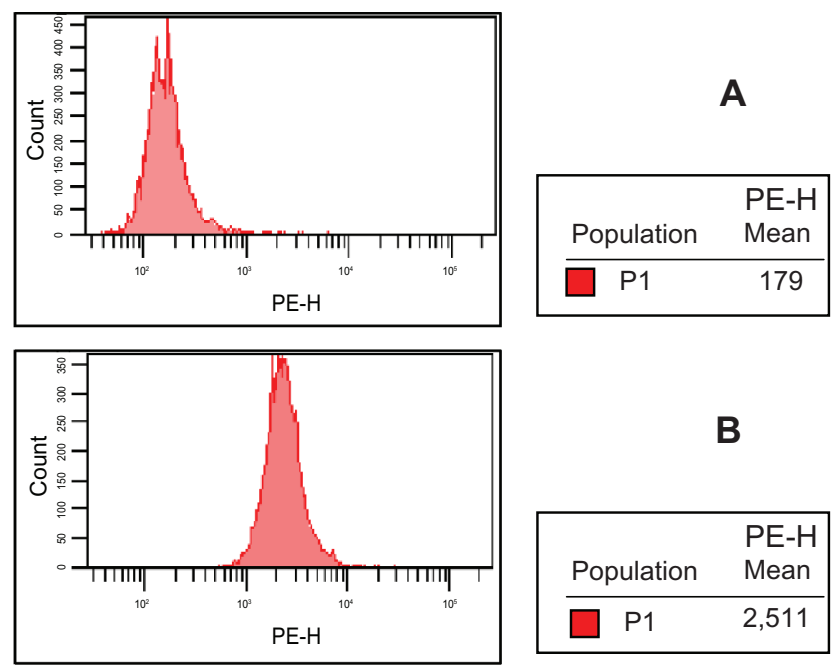

B
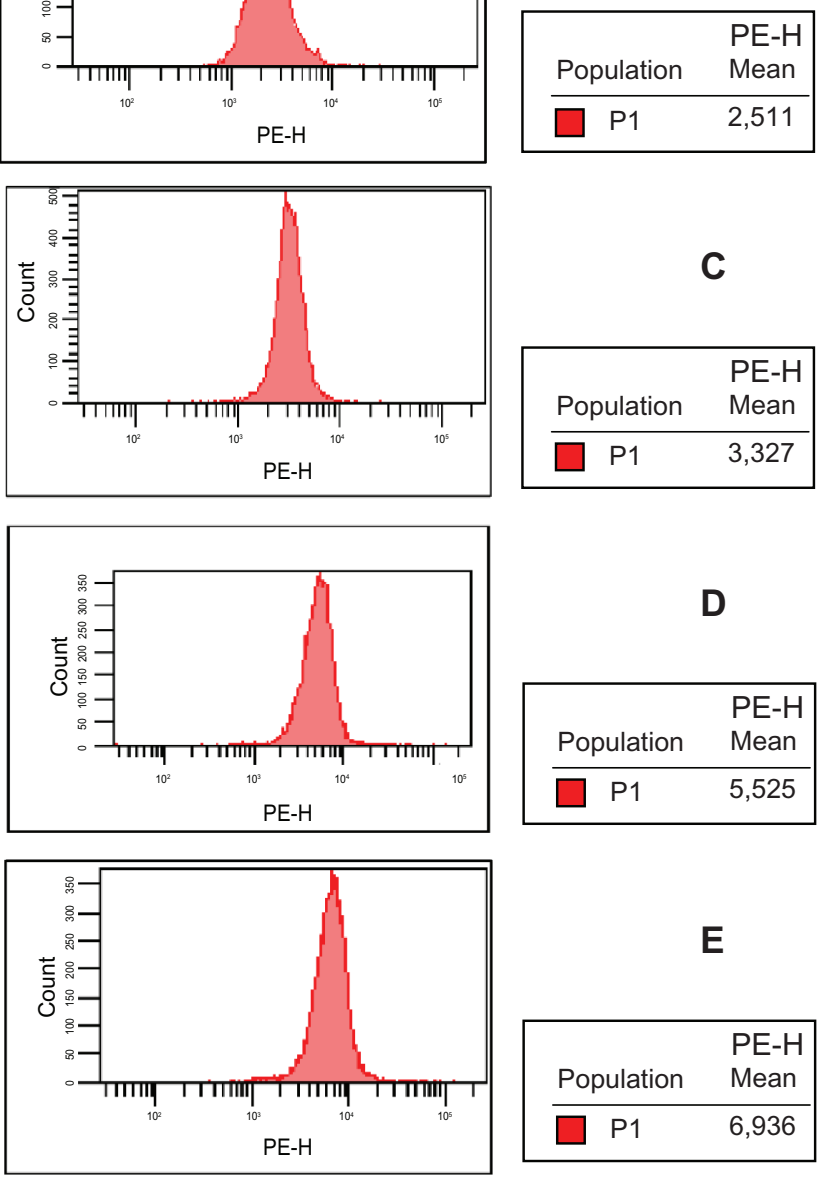

Figure 7 Intracellular accumulation of DNR in K562/A02 cells after treatment with different agent for 48 hours.

Notes: A) control (K562/A02); B) K562/A02 incubated with $1.0 \mu \mathrm{g} / \mathrm{mL}$ DNR; C) $\mathrm{K} 562 / \mathrm{A02}$ incubated with $1.0 \mu \mathrm{g} / \mathrm{mL}$ DNR and $10 \mu \mathrm{g} / \mathrm{mL} \mathrm{MNP}\left(\mathrm{Fe}_{3} \mathrm{O}_{4}\right)$; D) K562/ A02 incubated with $1.0 \mu \mathrm{g} / \mathrm{mL}$ DNR and PGYI-2; E) K562/A02 incubated with $1.0 \mu \mathrm{g} / \mathrm{mL} \mathrm{DNR}, 10 \mu \mathrm{g} / \mathrm{mL} \mathrm{MNP}\left(\mathrm{Fe}_{3} \mathrm{O}_{4}\right)$ and PGYI-2.

Abbreviations: MNP $\left(\mathrm{Fe}_{3} \mathrm{O}_{4}\right)$, magnetic nanoparticles of $\mathrm{Fe}_{3} \mathrm{O}_{4}$; DNR, daunorubicin.

transient settings have been available, which are of limited value if the target proteins display a long half-life. ${ }^{19}$ This problem may be circumvented by the use of viral systems for the stable expression of siRNAs. However, their pathogenicity, laborious production, and systemic instability limit their broad application, ${ }^{20}$ at present, a lot of research showed that the use of shRNAs, which expressed from stable integrated plasmids, can reduce MDR1 mRNA in K562/A02 cells. ${ }^{20}$ Our present toxicity results clearly indicated that the inhibitory activity of MNP $\left(\mathrm{Fe}_{3} \mathrm{O}_{4}\right)$ and PGY1-2 was significantly greater than that of PGY1-2 or MNP $\left(\mathrm{Fe}_{3} \mathrm{O}_{4}\right)$ alone at the same dose in the K562/A02 cells. The fold reversals were 15.3 of the synergia compared with the 3.15 of $\mathrm{MNP}\left(\mathrm{Fe}_{3} \mathrm{O}_{4}\right)$ and 13.7 of PGY1-2 alone. Furthermore, the transcription of MDR1 in K562/A02 cells preincubated with DNR in the absence or presence of $\mathrm{MNP}\left(\mathrm{Fe}_{3} \mathrm{O}_{4}\right)$ or vector PGY1-2 was higher when compared to parented sensitive K562 cells, furthermore, DNR with MNP $\left(\mathrm{Fe}_{3} \mathrm{O}_{4}\right)$ and PGY1-2 decreased the transcription of MDR1 mRNA in K562/A02 cells more effectively than with MNP $\left(\mathrm{Fe}_{3} \mathrm{O}_{4}\right)$ or with PGY1-2 alone, suggesting that combination of MNP $\left(\mathrm{Fe}_{3} \mathrm{O}_{4}\right)$ and PGY1-2 has a potential benefit to down-regulate the transcription of MDR1 mRNA, we also found that MNP $\left(\mathrm{Fe}_{3} \mathrm{O}_{4}\right)$ and PGY1-2 with DNR together decreased the expression of P-gp more effectively than MNP $\left(\mathrm{Fe}_{3} \mathrm{O}_{4}\right)$ or PGY1-2 with DNR alone $(P<0.05)$, suggesting that a combination of $\mathrm{MNP}\left(\mathrm{Fe}_{3} \mathrm{O}_{4}\right)$ and PGY1-2 also has a potential benefit to down-regulate the expression of P-gp. Interestingly, the expression levels of P-gp were in accordance with the transcription MDR1 levels of mRNA. Therefore, MNP $\left(\mathrm{Fe}_{3} \mathrm{O}_{4}\right)$ and PGY1-2 could synergistically reverse MDR. To obtain more data supporting this theory, further in vitro and in vivo studies are required.

\section{Conclusion}

Our study demonstrates for the first time that $\mathrm{MNP}\left(\mathrm{Fe}_{3} \mathrm{O}_{4}\right)$ and shRNA expression vector significantly reversed MDR, and the distinct synergistic effect of which owes to the downregulation of expression of mdr1 gene, suggesting that a combination of MNP $\left(\mathrm{Fe}_{3} \mathrm{O}_{4}\right)$ and shRNA expression vector may be a more sufficient and less toxic anti-MDR method.

\section{Acknowledgments}

This work was supported by National Natural Science Foundation of P.R. China (No. 30740062 and No. 39970832) and High School Doctor Subject Special-purpose Scientific Research Foundation (No. 20070286042).

\section{Disclosure}

The authors report no conflicts of interest relevant to this study.

\section{References}

1. Sarkar FH, Li Y. Using chemo preventive agents to enhance the efficacy of cancer therapy. Cancer Res. 2006;66(7):3347-3350.

2. Lin BL, Shen XD, Cui S. Application of nanosized $\mathrm{Fe}_{3} \mathrm{O}_{4}$ in anticancer drug carriers with target-orientation and sustained-release properties. Biomed Mater. 2007;2(2):132-134. 
3. Cheng FY, Su CH, Yang YS, et al. Characterization of aqueous dispersions of $\mathrm{Fe}_{3} \mathrm{O}_{4}$ nanoparticles and their biomedical applications. Biomaterials. 2005;26(7):729-738.

4. Zhang RY, Wang XM, Wu CH, et al. Synergistic enhancement effect of magnetic nanoparticles on anticancer drug accumulation in cancer cells. Nanotechnology. 2006;17(14):3622-3626.

5. Song M, Zhang R, Dai Y, et al. The in vitro inhibition of multidrug resistance by combined nanoparticulate titanium dioxide and UV irradiation. Biomaterials. 2006;27(23):4230-4238.

6. Wang X, Zhang $\mathrm{R}$, Wu C, et al. The application of $\mathrm{Fe}_{3} \mathrm{O}_{4}$ nanoparticles in cancer research: A new strategy to inhibit drug resistance. J Biomed Mater Res A. 2007;80A(4):852-860.

7. Sun Q, Chen BA, Wang XM, et al. Preparation of $\mathrm{Fe}_{3} \mathrm{O}_{4}$-magnetic nanoparticles loaded with Adriamycin and its reversal of multidrug resistance in vitro. J Exper Hematol. 2007;15(4):748-751.

8. Chen BA, Lai BB, Cheng J, et al. Daunorubicin-loaded magnetic nanoparticles of $\mathrm{Fe}_{3} \mathrm{O}_{4}$ overcome multidrug resistance and induce apoptosis of K562-n/VCR cells in vivo. Int J Nanomedicine. 2009;4:201-208.

9. Leung RK, Whittaker PA. RNA interference: from gene silencing to gene-specific therapeutics. Pharmacol Ther. 2005;107(2):222-239.

10. Liang YJ, Chen ZS, et al. Reversal of MDR1/P-glycoprotein-mediated multidrug resistance by vector-based RNA interference in vitro and in vivo. Cancer Biol Ther. 2006;5(1):39-47.

11. Bot I, Guo J, Van EM, et al. Lentiviral shRNA silencing of murine bone marrow cell CCR2 leads to persistent knockdown of CCR2 function in vivo. Blood. 2005;106(4):1147-1153.

12. Caplen NJ, Parrish S, Imani F, Fire A, Morgan RA. Specific inhibition of gene expression by small double-stranded RNAs in invertebrate and vertebrate systems. Proc Natl Acad Sci U S A. 2001;98(17): 9742-9747.
13. Alemán C, Annereau JP, Liang XJ, et al. P-glycoprotein, expressed in multidrug resistant cells, is not responsible for alterations in membrane fluidity or membrane potential. Cancer Res. 2003;63(12):3084-3091.

14. Gao H, Wang J, Shen X, et al. Preparation of magnetic polybutylcyanoacrylate nanospheres encapsulated with aclacinomycin A and its effect on gastric tumor. World J Gastroenterol. 2004;10(14):2010-2013.

15. Elbashir SM, Lendeckel W, Tuschl T. RNA interference is mediated by 21-and 22- nucleotide RNAs. Genes Dev. 2001;15(2):188-200.

16. Narvaiza I, Aparicio O, Vera M, et al. Effect of adenovirus mediated RNA interference on endogenous microRNAs in a mouse model of multidrug resistance protein 2 gene silencing. J Virol. 2006;80(24): 12236-12247.

17. Willner I, Willner B. Functional nanoparticle architectures for sensoric, optoelectronic and bioelectronic applications. Pure Appl Chem. 2002; 74(9):1773-1783.

18. Fojo T, Bates S. Strategies for reversing drug resistance. Oncogene. 2003;22(47):7512-7523.

19. Stierle V, Laigle A, Jolles B. The reduction of p-glycoprotein expression by small interfering RNAs is improved in exponentially growing cells. Oligonucleotides. 2004;14(3):191-198.

20. Gonzalez-Alegre P. Therapeutic RNA interference for neurodegenerative diseases: From promise to progress. Pharmacol Ther. 2007; 114:34-55.
International Journal of Nanomedicine

\section{Publish your work in this journal}

The International Journal of Nanomedicine is an international, peerreviewed journal focusing on the application of nanotechnology in diagnostics, therapeutics, and drug delivery systems throughout the biomedical field. This journal is indexed on PubMed Central, MedLine, CAS, SciSearch $\AA$, Current Contents ${ }^{\circledR} /$ Clinical Medicine,

\section{Dovepress}

Journal Citation Reports/Science Edition, EMBase, Scopus and the Elsevier Bibliographic databases. The manuscript management system is completely online and includes a very quick and fair peer-review system, which is all easy to use. Visit http://www.dovepress.com/ testimonials.php to read real quotes from published authors. 